\title{
Jednodniówki kulturalno-literackie na terenach wschodnich II Rzeczypospolitej
}

Streszczenie: Przedmiotem artykułu są jednodniówki kulturalno-literackie z obszaru województw wschodnich (nowogródzkiego, poleskiego, wileńskiego i wołyńskiego) II Rzeczypospolitej. Scharakteryzowano ich cechy, geografię wydawniczą (miejsca wydania), sposób przekazu, tematykę oraz odzwierciedlono zróżnicowanie etniczno-językowe (druki polskie i mniejszości narodowych), jak również społeczne (instytucje, organizacje autorsko-sprawcze, wydawcy, adresaci).

Słowa-klucze: jednodniówki kulturalno-literackie, źródła, Kresy, II Rzeczpospolita, województwa wschodnie.

\section{Cultural and literary one day's papers in the Eastern Voivode- ships of the 2nd Polish Republic}

Summary: This article focuses on cultural and literary one day's papers in the eastern voivodeships of the $2^{\text {nd }}$ Polish Republic (Novogrodek, Pole-

* Katarzyna Zimnoch - dr, pracownik Zakładu Filologicznych Badań Interdyscyplinarnych na Wydziale Filologicznym Uniwersytetu w Białymstoku. Dziedziny zainteresowań: historia książki, prasy, wydawców i bibliotek, zbiory specjalne, historia i teoria kultury. Aktualnie realizowane tematy: historia książki i bibliotek w II Rzeczypospolitej. Autorka m.in. książek: Jednodniówki na terenie województwa białostockiego i województw wschodnich Drugiej Rzeczypospolitej (Białystok 2017; wspólnie z J. Sadowską), Wieś Zimnochy w świetle tradycji historycznej od XV do XX wieku (Białystok 2006). 
sie, Vilnius, Volyn). Their character, publishing geography (places of publications), communication method and subject, as well as ethniclinguistic diversity (Polish and national minorities' publications) and social diversity (institutions, authoring and editing organizations, publishers, addressees) are presented.

Key words: cultural and literary one day's papers, sources, Borderlands, $2^{\text {nd }}$ Polish Republic, eastern voivodeships.

Na początku XX wieku Jan Obst pisał z przekonaniem: „Wadą badaczów naszej przeszłości z jej zabytkami historycznemi i artystycznemi jest pewna centralizacja. Podczas, gdy taki Kraków skupił co najwybitniejsze siły nasze naukowe, gdy tam każdy kamień niemal wszechstronnie opisany i sfotografowany, inne miejscowości - prowincje całe - jak gdyby nie istniały, jak gdyby nie przechował się tam ślad kultury naszej, lub też wcale kultura tam nie dotarła. Jest to mniemanie mylne..."1. Pomimo upływu lat, poczynionych licznych badań, w wielu przypadkach słowa te są nadal aktualne. Dotyczą one także dziejów życia literackiego, kulturalnego województw wschodnich II Rzeczypospolitej. Powstały liczne opracowania, zwłaszcza dotyczące Wileńszczyzny, ale mniej interesowano się innymi regionami przedwojennej wschodniej Polski. Uwzględniając strukturę zawodową i infrastrukturę tych ziem, należy stwierdzić, że pewne zjawiska kulturowe występowały tutaj w mniejszym nasileniu niż w innych województwach Polski, a zwłaszcza w ośrodkach uniwersyteckich. Do lepszego rozpoznania życia literackiego mogą służyć wciąż rzadko wykorzystane źródła, jakimi są jednodniówki.

W przedstawionym artykule chcemy zwrócić uwagę na jednodniówki kulturalno-literackie wydane w województwach nowogródzkim, poleskim, wileńskim i wołyńskim, zaliczanych w II Rzeczypospolitej do województw wschodnich $^{2}$. Ten podział (województwa centralne, wschodnie, zachodnie

1 J. O., Freski w kościele Mścisławskim, „Litwa i Ruś” 1912, t. II, z. I, s. 28.

2 Charakterystyka tych województw pod względem podziału administracyjnego, ludności, szkolnictwa, oświaty i kultury znajduje się w: J. Sadowska, K. Zimnoch, Jednodniówki na terenie województwa białostockiego i województw wschodnich (nowogródzkiego, poleskiego, wileńskiego, wołyńskiego) Drugiej Rzeczypospolitej, Białystok 2017, s. 30-60. 
i południowe) był pewną reminiscencją dawnych prowincji zaborczych. Zbliżone tematycznie są jednodniówki humorystyczno-satyryczne, a w dalszej kolejności społeczne, szkolne i oświatowe. Zostaną one tutaj jedynie zasygnalizowane, gdyż zasługują na osobne omówienie.

Definicje jednodniówek były już niejednokrotnie omawiane. Najczęściej podkreślano, że są to druki ulotne, efemerydy, wydawnictwa okolicznościowe, pod względem formy wydawniczej plasujące się na pograniczu druków zwartych i ciągłych. Jednodniówki często zapoczątkowywały lub zastępowały czasopisma. Zwracano uwagę na takie ich cechy, jak charakter okolicznościowy, aktualność informacji, obecność w życiu społecznym, politycznym i kulturalnym, szybkie reagowanie na bieżące wydarzenia. Ich cel sprowadzał się częstokroć do osiągnięcia doraźnych celów informacyjnych, propagandowych, reklamowych ${ }^{3}$. Trzeba jednak zauważyć, że jednodniówki często były miejscem publikacji utworów literackich. Znanym przykładem są jednodniówki futurystyczne. Utwory literackie, często debiutanckie, publikowano w jednodniówkach mniejszości narodowych w dwudziestoleciu międzywojennym.

Jednodniówki były adresowane do różnych grup społecznych, narodowych, zawodowych. Z punktu widzenia instytucji i organizacji wydawniczo-sprawczych oraz adresatów wymienia się jednodniówki młodzieżowe, partyjno-polityczne, wojskowe, kulturalno-literackie, zawodowe, administracyjno-samorządowe, społeczne, religijne oraz sportowe. Ze względu na zakres tematyczny, który mimo że był niemalże nieograniczony, wyodrębniono jednodniówki: polityczno-agitacyjne, patriotyczno-historyczne, społeczne, kulturalno-literackie, humorystyczno-satyryczne, szkolne i oświatowe, reklamowoinformacyjne, religijno-wyznaniowe oraz jubileuszowe.

3 Encyklopedia wiedzy o prasie, pod red. J. Maślanki, Wrocław 1976, s. 111; Encyklopedia wiedzy o książce, red. A. Birkenmajer, B. Kocowski, J. Trzynadlowski, Wrocław 1971, kol. 1067; J. Muszkowski, Życie książki, Łódź-Warszawa 2015, s. 171-172; Z. Głowicka, Dokumenty życia społecznego w zbiorach Biblioteki Narodowej, „Biuletyn Informacyjny Biblioteki Narodowej” 2001, nr 1 (156), s. 4; M. Korczyńska-Derkacz, Jednodniówki jako typ dokumentów życia społecznego. Zarys problematyki badawczej, „Acta Universitatis Wratislaviensis. Bibliotekoznawstwo" 2008 (27), s. 136; Taż, Polskie jednodniówki okresu międzywojennego jako źródło informacji o życiu młodzieży akademickiej Lwowa (ze zbiorów Biblioteki Narodowej), [w:] Kraków-Lwów: ksiązki, czasopisma, biblioteki XIX i XX wieku. t. 9, cz. 2, pod red. H. Kosętki, B. Góry, E. Wójcik, Kraków 2009, s. 205-218 oraz J. Sadowska, K. Zimnoch, dz. cyt., s. 14-19. 
W grupie jednodniówek kulturalno-literackich można wskazać jednodniówki: literackie, teatralne, filmowe, radiowe, cyrkowe, muzyczne, śpiewacze. $Z$ kolei z punktu widzenia adresatów wykrystalizował się wyraźny podział według kryteriów etniczno-językowych (polskie, żydowskie, litewskie, białoruskie, ukraińskie, niemieckie, rosyjskie) ${ }^{4}$. Należy także pamiętać, że sprawa typologii jednodniówek, tak jak i czasopism, może być odmiennie traktowana przez różnych autorów 5 .

W badaniach jednodniówek posłużono się wykorzystywaną $\mathrm{w}$ analizie prasy tradycyjną formułą badawczą Harolda Lasswella: „Kto komunikuje?”, „Co komunikuje?”, ,Jakimi środkami?”, „Komu komunikuje?”, ,Z jakim skutkiem komunikuje?”. Uwzględniono także postulaty polskich badaczy: „Gdzie (skąd komunikuje)?”, „Kiedy i dlaczego (w jakich okolicznościach) komunikuje?”6. Odpowiedzi na te pytania pozwolą na lepsze poznanie literackich zainteresowań społeczności badanych ziem i ukazanie fragmentu jej życia kulturalno-literackiego.

\section{Miejsce wydania}

W województwach wschodnich wydano łącznie aż 667 jednodniówek7 Były to publikacje o tematyce kulturalno-literackiej i humorystyczno-satyrycznej, zawodowej, politycznej i społecznej oraz religijnej, wojskowej, paramilitarnej, sportowej, młodzieżowej. Jednodniówek, które można zakwalifikować do kulturalno-literackich, odnotowano 52 , a humorystyczno-satyrycznych $-17^{8}$. Kilka jednodniówek można zaliczyć zarówno do kulturalno-literackich, jak

4 Tamże, s. 20-22.

5 Zob. Encyklopedia wiedzy o prasie, dz. cyt.; J. Jarowiecki, B. Góra, Prasa lwowska w dwudziestoleciu międzywojennym. Próba bibliografii, Kraków 1994, s. 17, 200-221.

6 W. Pisarek, Analiza zawartości prasy, Kraków 1983; T. Goban-Klas, Media i komunikowanie masowe. Teorie i analizy prasy, radia, telewizji i Internetu, Warszawa 1999; T. Chrząstek, Czasopismo społeczno-kulturalne „,Nowa Kultura” (1950-1963). Studium historycznoprasoznawcze, „Dzieje najnowsze” 2005, (R. 37), t. 1, s. 175-182; M. Kafel, Prasoznawstwo. Wstęp do problematyki, Warszawa 1966, s. 121; P. Dubiel, Metody analizy zawartości prasy. (Geneza, charakterystyka, technika badawcza), [w:] Metody i techniki badawcze w prasoznawstwie, t. 1, Warszawa 1969, s. 40-41.

7 J. Sadowska, K. Zimnoch, dz. cyt., s. 181.

8 Dotyczy to pięciu jednodniówek: dwóch wileńskich, dwóch łuckich i jednej rówieńskiej. Ponadto, należy pamiętać, że z wielu jednodniówek o tematyce politycznej, społecznej, szkolnej można także wyekscerpować materiał kulturalno-literacki i humorystyczno-satyryczny. 
i humorystyczno-satyrycznych, nawet w podtytułach mają one określenie: ,,jednodniówka literacko-satyryczna” lub „literacko-humorystyczna”. Jednodniówki kulturalno-literackie stanowiły więc niespełna $8 \%$, a humorystyczno-satyryczne 2,5\% wszystkich jednodniówek wydanych w województwach wschodnich. Był to więc niewielki odsetek tego typu publikacji na tym obszarze.

Na pierwszy plan wysuwa się ogromna dysproporcja w liczbie wydanych jednodniówek kulturalno-literackich w poszczególnych województwach. Zwraca uwagę zdecydowana przewaga druków wileńskich (44 kulturalno-literackich i 14 humorystyczno-satyrycznych). Jest to dość oczywiste, biorąc pod uwagę, że Wilno było piątym co do wielkości miastem w II Rzeczypospolitej, centrum kulturalnym (teatry, kina, redakcje czasopism) i naukowym (Uniwersytet, liczne towarzystwa naukowe) Kresów północno-wschodnich. W mieście toczyło się bogate życie kulturalne, odbywały się różne uroczystości, uaktywniały się organizacje i stowarzyszenia. W pozostałych województwach wschodnich jednodniówki powstawały przede wszystkim w ich stolicach: Łucku (2 i 2 humorystyczno-satyryczne), Nowogródku (2) oraz Brześciu nad Bugiem i Pińsku (po 1)9 oraz większych miasteczkach tego regionu w: Równem (1 i 1 humorystyczno-polityczna), Dubnie (1) i Słonimie (2).

Niekiedy zwraca uwagę podwójny adres wydawniczy. Tak było w przypadku jednodniówki teatralnej „Cu di gastroln fun bawustn artist Rudolf Zaslawski: ejnmolike teater ojsgabe” [z pol. „Występy znanego artysty Rudolfa Zasławskiego"], która jako miejsce wydania ma podane Wilno i Pińsk, przy czym odnotowano, że za jej wydanie i zredagowanie odpowiedzialny był Szloma Kohn z Pińska. Badania nad jednodniówkami z województw wschodnich wskazują, że druków z podwójnym adresem wydawniczym, ale o innej tematyce, na tych terenach było dosyć dużo.

\section{Inicjatorzy wydawania}

Omawiane jednodniówki były wydawane przez różnego rodzaju instytucje oraz osoby indywidualne i grupy środowiskowe. Ich inicjatorami pozostawały komitety organizacyjne ważnych wydarzeń, np. Komitet Tygodnia Bibliotek

9 Ustawa z lutego 1921 roku określała Pińsk jako stolicę województwa poleskiego, natomiast jego siedzibą stał się Brześć nad Bugiem. Ten stan tymczasowy stał się trwały i Brześć nad Bugiem pozostał stolicą województwa. Zob. P. Cichoracki, Województwo poleskie 1921-1939. Z dziejów politycznych, Łomianki 2014, s. 71-72. 
w Słonimie (Komitet fun der Bibljotek-Wok), Komitet „Dni Mickiewiczowskich” w Nowogródku, Komitet Organizacyjny Nauczycieli Szkół Powszechnych w Wilnie, a także instytucje, takie jak teatr (teatry polskie w Wilnie i Towarzystwo Przyjaciół Teatru Żydowskiego w Wilnie) i radio (Radiostacja Wileńska oraz Regionalny Społeczny Komitet Radjofonizacji Kraju w Wilnie). Wydawały je również środowiska dziennikarskie (redakcja „Woliner Prese” i Kółko Literatów i Dziennikarzy Żydowskich na Wołyniu) i abiturienci szkół (np. absolwenci gimnazjum „Tarbut” w Pińsku).

Jednodniówki kulturalno-literackie publikowali zarówno Polacy, jak i Żydzi, Litwini i Białorusini. W tym miejscu należy poczynić trzy uwagi. Po pierwsze, brakuje ukraińskich jednodniówek o tematyce kulturalno-literackiej wydanych w omawianych województwach, zwłaszcza wołyńskim. Prawdopodobnie jest to wynik bliskości Lwowa, gdzie mogły być one drukowane. Po drugie, warto zwrócić uwagę, że tego typu jednodniówki białoruskie i litewskie wydane zostały tylko w Wilnie, mimo że skupiska tych mniejszości narodowych znajdowały się także w innych miejscowościach. Ponownie potwierdza to, że Wilno jako ośrodek centralny dominował nad ościennymi województwami i mniejszymi regionami.

Trzecim spostrzeżeniem, jest fakt, że żydowskie jednodniówki kulturalno-literackie były wydawane we wszystkich badanych województwach, nawet w poleskim, gdzie opublikowano jedynie dwie - w języku jidysz i hebrajskim. Marian Fuks zwrócił uwagę, że niekiedy żydowska prasa prowincjonalna przewyższała polską ${ }^{10}$. W przypadku badanych jednodniówek, w województwach wschodnich, wydano tyle samo druków polskich, co żydowskich. Jednak należy pamiętać, że jedna kategoria jednodniówek jest tylko pewnym wycinkiem całego obrazu ruchu wydawniczego na tym obszarze.

\section{Okoliczności}

Jednodniówki wydawano z okazji ważnych wydarzeń kulturalnych, takich jak wizyty przedstawicieli świata artystycznego (np. przybycie do Polski żydowskiego poety „odnowiciela poezji hebrajskiej” Chajima Nachmana Bialika w 1931 roku czy też występów artysty Rudolfa Zasławskiego w 1928 roku), tygodnia bibliotek (1928 rok) oraz przedstawień teatralnych (przede wszyst-

10 M. Fuks, Materiaty do bibliografii żydowskiej prasy prowincjonalnej wydawanej w Polsce (1918-1939), „Biuletyn Żydowskiego Instytutu Historycznego” 1981, nr 2, s. 65. 
kim jednodniówki antraktowe 1924-1931, 1935 rok). Powstało kilka druków z okazji jubileuszy (np. 10-lecie radiostacji wileńskiej, 1938 rok), w tym związanych z upamiętnieniem Adama Mickiewicza (z okazji stulecia wydania Pana Tadeusza w 1934 roku oraz Dni Mickiewiczowskich w 1938 roku). Jednodniówki kulturalno-literackie na tych terenach powstawały również z okazji świąt, zwłaszcza Bożego Narodzenia. Znaczną część tego typu druków wydawano, żeby, jak sygnalizowano, popularyzować literaturę i sztukę.

Przyczyny powstania omawianych jednodniówek były bardzo zróżnicowane. W jednodniówce „Mickiewiczowi 1834-1934” we wstępie napisano „W stuletnią rocznicę wydania Pana Tadeusza cała Polska hołd składa naszemu wielkiemu poecie - Adamowi Mickiewiczowi. Jest on chlubą i dumą naszego narodu. Jeśli zapytamy, dlaczego właśnie Mickiewicza wyróżniamy z pośród innych i większą go miłością otaczamy - odpowiedź na to jest prosta: Widocznie Mickiewicz wrył się nam w serca głęboko i okazji jeno szukamy, by wyrazić mu nasze zawsze żywo bijące dla niego uczucia. My naszego wieszcza uwielbiamy, kochamy!"'11.

Redakcja jednodniówki „W nowogródzkiej stronie” we wstępie (Od Redakcji) wyjaśniała, że „Komitet organizacyjny «Dni Mickiewiczowskich» postanowił uczcić to święto Nowogródczyzny wydaniem niniejszej jednodniówki”. Planowano powtarzać tę inicjatywę cykliczne i zapewniano, że ,już w następnych latach na coroczne «Dni Mickiewiczowskie» będą niezawodnie lepsze możliwości wydania takiej jednodniówki”'12. Redaktor jednodniówki w artykule Nowogródczyzna pisał: „Miejmy nadzieję, że «Dni Mickiewiczowskie» walnie przyczynią się do spopularyzowania Nowogródczyzny, nazywanej dość często «Ziemią Mickiewicza»"13. Sławę tego miejsca chciano wykorzystać nie tylko do wydania materiałów dotyczących najbardziej znanej postaci związanej z tymi ziemiami, ale też do zaprezentowania walorów turystycznych i potencjału gospodarczego owego miejsca.

Niemal we wszystkich jednodniówkach zamieszczone były reklamy. Często to dzięki nim można było sfinansować wydanie druku. Świadczą o tym

11 „Mickiewiczowi 1834-1934: jednodniówka ku uczczeniu 100-letniej rocznicy «Pana Tadeusza» poświęcona wileńskiej dziatwie szkolnej”, Wilno 1934, s. 1.

12 Od Redakcji, „W nowogródzkiej stronie: jednodniówka wydana nakładem komitetu «Dni Mickiewiczowskich» w Nowogródku”, Nowogródek 1938, s. 1.

13 G. Engman, Nowogródczyzna, „W nowogródzkiej stronie...”, dz. cyt., s. 2. 
zamieszczane podziękowania, np. „(...) wszystkim firmom chrześcijańskim, które w postaci udzielenia ogłoszeń - umożliwiły sfinansowanie tego wydawnictwa" 14 . Reklamowały się miejscowe firmy i sklepy różnych branż. Były to ogłoszenia tekstowe, a także w postaci graficznej lub w formie wierszowanej. Niewiele firm bądź produktów wiązało się z książką i prasą, nieco więcej ze sprzętem radiowym. Niekiedy, przy okazji starano się pozyskać fundusze na jakieś ważne przedsięwzięcia. Taką inicjatywę w badanych jednodniówkach zauważono dwukrotnie - w grudniu 1918 roku, wówczas 25\% dochodu chciano przeznaczyć na samoobronę i Wojsko Polskie oraz w lutym 1920 roku $10 \%$ dochodu na powstający w Wilnie szpital wojskowy.

\section{Zawartość}

Zawartość jednodniówek była bardzo różnorodna. Zazwyczaj były to zbiory rozmaitych utworów (publicystycznych i literackich), często wzbogacone fotografiami lub rysunkami, dokumentującymi prezentowane inicjatywy, wydarzenia, osoby i instytucje. Wydawnictwa te obok materiałów, które można zaliczyć do kulturalno-literackich, zawierały też inne artykuły dające przegląd osiągnięć z zakresu oświaty, kultury, handlu i przemysłu, rzemiosła i kupiectwa oraz aktualnych potrzeb danego miasta czy też ziemi. Generalnie tematyka jednodniówek skupiona była przede wszystkim na sprawach lokalnych, zarówno w zakresie informacji, kroniki regionalnej, publicystyki, aż po różnego rodzaju ogłoszenia i reklamy. Niekiedy na marginesie pojawiały się wiadomości ze świata i kraju, zwłaszcza chętnie publikowano różnego rodzaju ciekawostki. Ażeby zaprezentować zawartość jednodniówek chcielibyśmy zanalizować bliżej kilka głównych tematów, które były poruszane na ich łamach.

\section{„W nowogródzkiej stronie”; „Mickiewiczowi (1834-1934)”}

Dość oczywiste wydaje się wydanie w województwach wschodnich II Rzeczypospolitej jednodniówek poświęconych Adamowi Mickiewiczowi, zwłaszcza w Nowogródku, miejscu związanym z jego dzieciństwem, przestrzeni jego pierwszych ,rozpoznań” oraz w Wilnie wykreowanym przez poetę na ,miasto święte”, ziemię utraconą i obiecaną. W obu publikacjach „W nowogródzkiej stronie” oraz „Mickiewiczowi (1834-1934)” znalazły się artykuły dotyczące

\footnotetext{
14 Od Redakcji, „W nowogródzkiej stronie...”, dz. cyt., s. 1.
} 
poety, jego życia, twórczości zobrazowane licznymi cytatami z jego poezji oraz fragmentami korespondencji. Ciekawie osnuto treść dwóch artykułów - Dwie wiosny (1812 i 1919), gdzie ukazano młodzieńca w obliczu bardzo ważnych wydarzeń dla tych ziem - wyprawy Napoleona oraz wyzwolenia Wilna, którego poeta nie mógł być już świadkiem oraz Film czarodziejski, w którym to artykule poemat Mickiewicza porównano do żywego filmu ${ }^{15}$.

Aleksander Śnieżko, autor jednego z artykułów, podkreślał, że „miejsca, na których przebywali niegdyś wielcy ludzie, owiane są zawsze jakimś nieuchwytnym poetyckim urokiem, z chwilą ich śmierci, pamięć i cześć dla tych miejsc nie tylko nie ginie, lecz z czasem jeszcze większą zyskuje powagę i szacunek w następnych pokoleniach". Wtórował mu Władysław Abramowicz, a Aniela Fleszarowa konstatowała, że twórczość Adama Mickiewicza jest dokumentem polskości Nowogródczyzny. Zwracano także uwagę, że „Nowogródek winien stać się tym centrum dla życia kulturalnego jakiego w olbrzymim trójkącie Wilno - Białystok - Brześć - aż do granicy wschodniej poza Nowogródkiem brak"16. Ponadto, w jednej z jednodniówek umieszczono dość obszerne artykuły o stanie i potrzebach gospodarczych, rzemiośle, kupiectwie i fabrykach województwa nowogródzkiego. Miało to służyć promocji regionu wykorzystując sławę tych „Mickiewiczowskich ziem”.

Uwagę zwracają wiersze poświęcone nowogródzkiej ziemi i Mickiewiczowi, które realizują niejako program - ukazywanie tego, co na tych terenach najcenniejsze. Słowo poetyckie miało służyć wychwalaniu krajobrazu, zwłaszcza nowogródzkiego, jak w wierszach Anieli Fleszarowej Uśmiech Świtezi i Dymitra Mieczysława Kasatego Świteź w nocy. Ponadto, w jednym z artykułów przypomniano pierwszą redakcję zwrotek ballady Adama Mickiewicza To lubię, która pierwotnie powstała dla Joasi, pierwszej ukochanej poety ${ }^{17}$. Większość z tych materiałów zmierza do nieskomplikowanego stwierdzenia, które

15 „Mickiewiczowi (1834-1934)...”, s. 4-5: Dwie wiosny (1812 i 1919 r.); s. 8-11: Film czarodziejski.

16 „W nowogródzkiej stronie...”, dz. cyt., s. 10: A. Śnieżko, Dworek Mickiewiczowski w Nowogródku; s. 6: W. Abramowicz, Sny Mickiewicza o szczęściu z Marylą; s. 7-9: A. Fleszarowa, Twórczość Adama Mickiewicza-jako dokument polskości Nowogródczyzny, oraz s. 19: W. Skarżyński, Stan i potrzeby gospodarcze województwa nowogródzkiego.

17 J. Kallenbach, O nieznanych utworach młodzieńczych Adama Mickiewicza, „Pamiętnik Literacki" 1908, t. 7, nr 1-4, s. 493-494. 
sformułował w jednej z publikacji redaktor niniejszej jednodniówki, Grzegorz Engman: ,piękno tej ziemi, tradycje, legendy i podania ludowe były źródłem natchnienia i twórczości Wieszcza"18.

\section{Popularyzacja literatury mniejszości narodowych}

$\mathrm{Na}$ omawianym obszarze, jednodniówki wydawali, obok ludności polskiej, Żydzi, Litwini i Białorusini. Są to bardzo zróżnicowane materiały pod względem formy i treści. Miały one przede wszystkim, jak wskazuje dodatek do tytułu jednej z nich - ,popularyzować literaturę i sztukę"19.

W latach 1937-1938 litewskie środowisko młodych literatów i inteligencji lewicowej wydało w Wilnie siedem jednodniówek. Pierwszą była „Varsnos” [z pol. „Skiba”], zawierająca wiersze, opowiadania, drzeworyty młodych twórców litewskich. Następne jednodniówki tej grupy to: „Varpos” [z pol. „Kłosy”], „Vingis” [z pol. „Zakręt”], „Pjūvis” [z pol. „Przekrój”], „Sèja” [z pol. „Siejba”/ „Siew”], „Vienkartinis : mosklui, dailei ir literatūrai populiarinti vienkartinis leidinys” [z pol. „Jednodniówka : promująca naukę, sztukę, literaturę”], „Versmė” [z pol. „Krynica”] ${ }^{20}$. Tylko jedną jednodniówkę firmował Wileński Związek Studentów Litewskich. Jej redaktorami byli: Jonas Karosas, Vlada Rusokaite, J. Pivoriūnas, J. Aidulis, Z. Prantkelevičius, Vladas Drèma. Najbardziej zaangażowany był Jonas Karosas, znany często pod pseudonimem „J. Dagys”, autor wielu artykułów na temat życia literackiego Wilna ${ }^{21}$.

Jednodniówki litewskie promowały literaturę młodych twórców litewskich, zamieszczano w nich teksty literackie, o sztuce litewskiej, o inspiracjach młodych poetów ${ }^{22}$, recenzje, a także inne materiały, np. wyniki sondażu na temat literatury wileńskiej, jej perspektyw oraz warsztatu twórczego młodych pisarzy („Versmė”). Znalazły się także artykuły dotyczące literatury pol-

18 G. E. [Grzegorz Engman], Święto Nowogródczyzny, „W nowogródzkiej stronie...”, dz. cyt., s. 13 .

19 „Vienkartinis: mokslui, dailei ir literaturai populiarinti vienkartinis leidinys” [pol. tł. tyt. ,Jednodniówka: jednodniówka popularyzująca literaturę i sztukę], Wilno 1938.

20 B. Makowski, Prasa litewskiej mniejszości narodowej w Polsce w latach 1920-1939, „Kwartalnik Historii Prasy Polskiej” 1978, nr 17/1, s. 103-104.

21 D. Balašaitenè, Litewska poezja międzywojennego Wilna, [w:] Poezja i poeci w Wilnie lat 1920-1940. Studia, pod red. T. Bujnickiego i K. Biedrzyckiego, Kraków 2003, s. 295-310.

22 Np. J. Dagys [J. Karosas], Albino Žukausko poezija, „Versmë”, Wilno 1939, s. 7. 
skiej, np. Juozasa Kèkštasa pt. Najnowsza poezja polska²3. Z jednodniówkami współpracowali znani literaci litewscy, m.in. J. Česnys, V. Čepulyte, V. Drèma, J. Karosas, A. Karužas, J. Kèkštas, M. Krinickaitė, O. Miciutė, J. Petkus, V. Rusokaitè, Z. Tureika, A. Žukauskas.

Większość jednodniówek litewskich zastępowała czasopisma, które ze względu na cenzurę były likwidowane lub zawieszane. Miały one też uzupełnić lukę wydawniczą mniejszości litewskiej. Należy przypomnieć, że głównym powodem ingerencji cenzury był sposób naświetlania w prasie litewskiej spraw narodowościowych i stosunków polsko-litewskich ${ }^{24}$.

Białoruskie środowisko literackie publikowało swoje utwory w wielu jednodniówkach, nie zawsze jednak o profilu literackim, choć w niektórych z nich tematyka ta dominowała, np.: „Bełaruskaja krynica” [z pol. „Krynica białoruska”], „Novagodnik” [z pol. „Noworocznik”], „Kaljada” [z pol. „Kolęda”], „Novaja malanka” [z pol. „Nowa błyskawica”]. Wśród redaktorów można wymienić m.in. Antona Prakapienię. Zamieszczano w nich wiersze przede wszystkim: Janki Kupały, Janki Drozda, Kazimira Swajaka, Chwiedara Iljaszewicza, Alesia Hurły, Franciszka Hryszkiewicza i Stanisława Stankiewicza. Kilkakrotnie publikowano utwory literackie Natalii Arseniewej, m.in. cykl wierszy Pieśni na czużynie oraz omawiano jej twórczość powstałą na emigracji („Novagodnik”, „Kaljada”). Na uwagę zasługuje także szkic o twórczości Uładzimira Żyłki, poety, znanego krytyka literackiego i tłumacza na język białoruski wielu wybitnych dzieł. W omawianych jednodniówkach można też znaleźć charakterystykę prasy białoruskiej oraz zmagania z cenzurą - zawieszenie przez władze czterech pism białoruskich: „Zmahańnie”, „Hołas Biełarusa”, „Syn Biełarusa” i „Sialanskaja Praŭda” („Kaljada”).

Należy też pamiętać, że Białorusini współpracowali z czasopismami takimi, jak: „Przegląd Wileński”, „Balticoslavica”, „Środy literackie”. O literaturze i białoruskim życiu literackim pisały: „Ateneum Wileńskie”, „Żagary”, „Słowo” oraz „Kurier Wileński”25.

23 J. Kèkštas, Najnowsza poezja polska, „Vienkartinis”, Wilno 1938.

24 Szczegóły zob. B. Makowski, Prasa litewskiej mniejszości narodowej w Polsce w latach 1920-1939, „Kwartalnik Historii Prasy Polskiej” 1978 (17), nr 1, s. 89-107.

25 T. Zienkiewicz, Z problematyki polsko-białoruskich związków literackich $w$ międzywojennym Wilnie (Białorusini i ich wspótpraca z „Przegladem Wileńskim”), [w:] Wilno literackie na styku kultur, pod red. T. Bujnickiego i K. Zajasa, Kraków 2007, s. 211. 
Z kolei żydowskie środowisko literackie wydało kilka jednodniówek w każdym omawianym województwie. Dwa interesujące druki kulturalno-literackie powstały w województwie poleskim. Pierwszy z nich ukazał się w 1928 roku w Brześciu nad Bugiem. Był to zbiór poezji młodzieży - „Jung-poezje: (zamelheft)” [z pol. „Poezja młodych: (zbiór)”]. Zredagował ją Icchak Perłow, znany poeta żydowski. Drugi opublikowano w 1931 roku w Pińsku na cześć żydowskiego poety Chaima Nachmana Bialika - „Gîdûlê-Tarbût” [z pol. „Wychowankowie Tarbutu"]. Można także wspomnieć o jednostronicowej jednodniówce wydanej w kwietniu 1928 roku w Słonimie „Bibljotek-Wok” [z pol. „Tydzień bibliotek"] w województwie nowogródzkim.

W latach trzydziestych XX wieku ukazały się żydowskie jednodniówki humorystyczne, wydawane przez literatów i dziennikarzy w województwie wołyńskim. Dwie z nich zatytułowane „Di 7-te [zibete] meluke” [z pol. „7-ma potęga świata"] powstały z okazji balów prasy żydowskiej w 1932 i 1934 roku. Obie zostały opublikowane w Łucku przez redakcję czasopisma „Woliner Prese". Jednym ze współredaktorów był dr Bejlin (Beilin) Bencjon, lekarz łucki, znany także jako działacz polityczny z ramienia Żydowskiej Partii Ludowej26. Trzecia żydowska jednodniówka „Ejgns” [z pol. „Własność”] wydana została w Równem przez Kółko Literatów i Dziennikarzy Żydowskich na Wołyniu. W Wilnie, w kwietniu i maju 1936 roku, w miejsce tygodnika literacko-społecznego „Zybn Teg” [z pol. „Siedem Dni”] pijawiły się trzy jednodniówki. Były to: „Undzere zibn teg: literariš-gezelšaftleke woknšrift” [z pol. „Nasze siedem dni: tygodnik literacko-społeczny”], „Naje zibn teg: literariš-gezelšaftleke woknšrift” [z pol. „Nowe siedem dni: tygodnik literacko-społeczny”] oraz „Di zibn teg: literariš-gezelšaftleke woknšrift” [z pol. „Siedem dni: tygodnik literacko-społeczny"].

\section{Jednodniówki teatralne}

Wilno było miastem, w którym w okresie międzywojennym funkcjonowały teatry polskie i żydowskie. Nie odnotowaliśmy tam jednak wielu wydawnictw poświęconych sprawom teatru. Materiały na ten temat zamieszczano najczęściej na łamach czasopism takich jak: „Tygodnik Wileński”, „Sztuka

26 Żydowska mozaika polityczna w Polsce 1917-1927: wybór dokumentów, wybór i oprac. Cz. Brzozy, Kraków 2003, s. 145. 
i Film” oraz „Wileński Przegląd Artystyczny. Tygodnik ilustrowany dla spraw teatru, muzyki, kinematografii, sztuk plastycznych, literatury i wychowania estetycznego". Franciszek Rychłowski, dyrektor Teatru Polskiego w Wilnie w latach dwudziestych ubiegłego stulecia próbował stworzyć czasopismo przyteatralne, ale niestety nie udało mu się tego pomysłu zrealizować. Wobec braku poważnego czasopisma o tej tematyce istniała potrzeba wydawania jednodniówek, które pozwoliły na ukazanie i udokumentowanie oraz promocję podejmowanych działań teatralnych. Opublikowano dwadzieścia tego typu druków. Były to w większości tzw. jednodniówki antraktowe, stanowiące dodatki do programów teatralnych. Z czasem zaczęto wydawać, choć nieregularnie i krótko, czasopisma teatralne: „Wiadomości Redutowe” (1925/1926-1930), „Front Teatralny” (1932-1938) oraz „Przed Kurtyną” (1933-1934), a od 1938 roku zagadnienia teatralne poruszano w piśmie „Comoedia. Pismo poświęcone sprawom sztuki i kultury współczesnej”27.

Wileńskie jednodniówki antraktowe wydawał Stefan Grabowski, właściciel Biura Reklamowego. Sprzedawano je w kasach biletowych oraz kioskach i księgarniach. W sezonie 1924-1925 wszystkie jednodniówki miały dodatek do tytułu właściwego ,wileńska jednodniówka antraktowa” oraz drugi dodatek określający sezon teatralny (np. „Gwiazdka: wileńska jednodniówka antraktowa: sezon 1924/1925"). W 1924 roku ukazały się tego typu jednodniówki o tytułach: „Za i przeciw”, „Iskry i wióry”, „Rozrywka”, „Gwiazdka”, „Panorama”, „Karnawał”, „Wilnianka”. W 1925 roku były to jednodniówki: „Półpoście” i „Jajeczko”. Podobne jednodniówki ukazywały się także w latach następnych: „Echo: jednodniówka teatralna” (1926) i jej kontynuacja „Nowe echo: jednodniówka teatralna” (1927). Następnie: „Jednodniówka teatralna w rocznicę listopadową: sezon 1930/31”, „Pożółkły listek: jednodniówka teatralna: sezon 1930/31”, „W rocznicę listopadową: jednodniówka teatralna: sezon 1930/31”, „Wieczory jesienne: jednodniówka teatralna: Wilno 1930/31”, „Aktor i maska: jednodniówka teatralna” (1931), „Pierwiosnki: jednodniówka teatralna: sezon 1931”, „Przedwiośnie teatralne: jednodniówka teatralna: sezon 1931”, jak również „Śnieżne płatki: jednodniówka teatralna: sezon 1931”.

Tematyka jednodniówek była bardzo zróżnicowana. Prawie zawsze dotyczyła ona bieżącego repertuaru, ale znaleźć w nich możemy np. spis arty- 
stów Teatrów Miejskich w Wilnie („Pożółkły listek”), czy też Credo dyrektora Aleksandra Zelwerowicza („Pożółkły listek”). Publikowano w nich składy zespołów poszczególnych spektakli teatralnych, sylwetki aktorów wileńskich (np. Karola Wyrwicza - „Panorama”), artystów (np. Adama Wyleżyńskiego „Iskry i Wióry”), dramaturgów (np. Nikołaja Jewrieinowa - „Za i przeciw”, Józefa Blizińskiego „Pożółkły listek”), zapowiedzi repertuarowe, recenzje granych spektakli, niekiedy wykazy sprawozdawców teatralnych („Echo”), bilanse sezonów teatralnych, z uwzględnieniem frekwencji na poszczególnych sztukach. Zamieszczano w nich przedruki z prasy wileńskiej. Zainicjowano prezentację dziejów teatru litewskiego („Nowe echo”). Informowano o różnych przedsięwzięciach teatralnych, m.in. o pierwszych poczynaniach Teatru Reduty w Wilnie (,Echo”). Interesowano się także innymi scenami teatralnymi, m.in. warszawską („Panorama”), a także teatrem rosyjskim (,Rozrywka”) i niemieckim („Echo”). Starano się dołączać dowcipy i ciekawostki (np. Szczypta humoru, Taniec i moda, Genjalni... Wielcy... Znakomici... Plotki... ploteczki..., Drobiazgi z całego świata - ciekawostki z życia teatralnego na świecie - „Pożółkły listek”).

Społeczność żydowska również wydawała jednodniówki teatralne. $Z$ teatrem żydowskim związane były trzy tego typu druki, z czego dwa wydało Towarzystwo Przyjaciół Teatru Żydowskiego w Wilnie, które powstało w 1928 roku i zasłynęło ze sprowadzania gościnnych zespołów i prowadzenia pracy oświatowej. Jedna $\mathrm{z}$ jednodniówek [, $\mathrm{Cu}$ di gastroln fun bewust artist Rudolf Zasławski” (z pol. „Na występ znanego artysty Rudolfa Zasławskiego")] poświęcona była temu wybitnemu aktorowi żydowskiemu. Zawierała wyciągi z prasy w kilku językach: jidysz, polskim, francuskim i rosyjskim. Zasławski był absolwentem szkoły dramatycznej w Odessie, a później dyrektorem Teatru Żydowskiego w Kijowie, po wojnie zamieszkał w Polsce - najpierw w Warszawie, a ostatecznie osiadł w Gdańsku, gdzie prowadził Teatr Żydowski.

$\mathrm{Z}$ treści jednodniówek teatralnych wynika, że miały one charakter przede wszystkim informacyjny i dokumentacyjny. Ich celem było upowszechnianie sztuki teatralnej, pozyskiwanie widzów dla teatru, odzwierciedlanie dążeń organizacji i stowarzyszeń ludzi związanych z teatrem, a przede wszystkim informowanie o najważniejszych wydarzeniach teatralnych w Wilnie. Sima Kaganowicz opisując żydowskie przedsięwzięcia teatralne w Wilnie, w tym 
Towarzystwo Przyjaciół Teatru Żydowskiego, które, jak już wspominano, wydało kilka jednodniówek, stwierdził, że takie jednorazowe publikacje tekstów ogólnych o teatrze czy też o danej sztuce miały podnieść poziom wiedzy artystycznej widzów ${ }^{28}$.

\section{Jednodniówki radiowe}

W Wilnie wydawano publikacje związane z działającą od 1928 roku rozgłośnią radiową. Jedną z nich była jednodniówka „Kresowy przegląd radjowy: jednodniówka poświęcona radiofonizacji województw północno-wschodnich" (1938 rok). Jest to bardzo cenny materiał dokumentujący działalność wileńskiego radia. Wart jest uwagi nie tylko ze względu na specyficzny regionalny charakter, ale także na podejmowane próby mające charakter niemalże eksperymentalny - znakomite słuchowiska radiowe, transmisje, emitowanie obszernych przedstawień teatralnych, programy literacko-artystyczne, w których brali udział poeci związani z Wileńszczyzną, m.in. Czesław Miłosz, Teodor Bujnicki i Jerzy Zagórski.

Były też audycje typowo związane z regionem i jego kulturą, np. gawędy „Ciotki Albinowej” i „Wincuka Markotnego”. Nadawano odczyty, pogadanki, koncerty, a także bieżące wiadomości również w języku litewskim i białoruskim. Warto zwrócić uwagę na znanych z tego okresu wileńskich spikerów: Wiktora Trościankę, Joannę Piekarską i Lecha Beynara, bardziej znanego ze swojego pseudonimu „Paweł Jasienica”. W jednej z omawianych jednodniówek zamieszczono ich zdjęcia. Wszyscy oni znani są dzisiaj ze swojej działalności pisarskiej, dziennikarskiej lub artystycznej. O roli rozgłośni wileńskiej pisano, że ,jako stacja kresowa miała w swej pracy programowej w ubiegłem dziesięcioleciu wiele zdobyczy, emanując na całą Polskę te wszystkie wartości twórcze i kulturalne, które w ciągu wieków nagromadziły się w skarbnicy Wileńszczyzny. Folklor, całe piękno i bogactwo naszych Ziem mogli poznać radiosłuchacze całej Polski za pośrednictwem mikrofonów wileńskich"29. Znaczenie rozgłośni wileńskiej podkreślał również artykuł Wandy Boye, która

28 S. Kaganowicz, Teatr żydowski w Wilnie, [w:] Wilno i Kresy pólnocno-wschodnie. Materiały II Międzynarodowej Konferencji w Białymstoku 14-17 IX 1994 r. w czterech tomach. T. II: Kultura i trwanie, pod red. E. Feliksiak i A. Kisielewskiej, Białystok 1996, s. 264.

29 J. Z. [Jerzy Zapaśnik], Radjo w każdym domu, „Kresowy przegląd radjowy: jednodniówka poświęcona radiofonizacji województw północno-wschodnich”, Wilno 1938, s. 1. 
odnosiła się do roli radia na kresach z punktu widzenia osoby mieszkającej w centrum kraju ${ }^{30}$.

W omawianej jednodniówce podkreślano rolę radia dla miasta i wsi, dla dorosłych i dla dzieci (Rozgłośnia Wileńska Dzieciom). Korzyści z audycji powinni widzieć rolnicy, gdyż radio jest swoistym „doradcą, który w porę udzieli właściwej i aktualnej wskazówki i przypomni o wszystkich zadaniach" ${ }^{\prime 1}$ czy też gospodynie domowe, które mogą traktować radio jako informatora zarówno w sprawach dotyczących prowadzenia domu, wychowywania dzieci, jak i działalności związków zawodowych i organizacji kobiecych na wsi (Dobra gospodyni korzysta z radja). Ciekawie prezentuje się artykuł pt. Jak stuchać radja?, w którym po omówieniu roli radia, znajdują się wskazówki korzystania z niego, np., że należy skupić się dłużej na jednej stacji radiowej, nie mieć stale włączonego odbiornika, odpowiednio dobierać audycję do słuchania biernego, korzystać z programów audycji (niż słuchać na chybił trafił), przy wyborze audycji uwzględnić w jakich warunkach będzie ona słuchana (w samotności, w towarzystwie innych osób). Zwracano również uwagę na odpowiednie wykorzystanie radia dla celów wychowawczo-oświatowych oraz na rolę współpracy. Niejednokrotnie podkreślano potrzebę zakupu odbiorników radiowych dla szkół i świetlic. Te wskazówki wyraźnie pokazują, że jednodniówka była skierowana do szerokiego kręgu odbiorców, również tych, którzy nie byli aktywnymi uczestnikami życia kulturalnego. Widziano więc $\mathrm{w}$ radiu możliwość wspierania i upowszechniania działań kulturalnych.

$\mathrm{Na}$ łamach omawianych jednodniówek poświęcono także trochę miejsca na sprawy techniczne związane $\mathrm{z}$ funkcjonowaniem rozgłośni wileńskiej. Wspominano o ciągłej jej modernizacji oraz organizowanych szkoleniach, takich jak Kurs przysposobienia radjowego w Wilnie dla starszej młodzieży Zwiazku Strzeleckiego oraz instruowano, co robić przy zakłóceniach radiowych (Walczymy z zaktóceniami $w$ odbiorze radjowym) ${ }^{32}$. W statucie Społecznego

30 W. Boye, Stowo w samodziałaniach, „Kresowy przegląd radjowy...”, dz. cyt., s. 13.

31 Nowy rok z odbiornikiem radjowym, „Kresowy przegląd radjowy..., dz. cyt., s. 3.

32 Tamże, s. 14: Rozgłośnia Wileńska Dzieciom; s. 3: Nowy rok z odbiornikiem radjowym; s. 12: Dobra gospodyni korzysta z radja; s. 10-11: Jak stuchać radja?; s. 6: Kurs przysposobienia radjowego w Wilnie dla starszej młodzieży Zwiazku Strzeleckiego oraz s. 9: Walczymy z zaktóceniami $w$ odbiorze radjowym. 
Komitetu Radiofonizacji Kraju sugerowano, że „Radjofonia jako nowoczesne narzędzie kultury, jako doskonały środek propagandy państwowej i wychowania obywatelskiego, jako wreszcie jeden z czynników dozbrojenia w zakresie łączności - zasługuje na jak największe rozpowszechnienie wśród ludności miejskiej i wiejskiej naszego Kraju"33.

\section{Jednodniówki świąteczne}

Ze względu na specyfikę badanego materiału należy także zwrócić uwagę na jednodniówki o tematyce świątecznej. Dwie z nich wydano w Wilnie („Gwiazdka wileńska : jednodniówka świąteczna”, 1926; „Gwiazdka: jednodniówka świąteczna artystyczno-literacka” 1936), a dwie w Łucku („Choinki płoną: świąteczna jednodniówka literacka, 1933; „W Bożą noc: jednodniówka świąteczna", 1936). Wszystkie dotyczyły Bożego Narodzenia.

Zakres tematyczny materiałów umieszczonych w omawianych jednodniówkach był bardzo podobny. Najczęściej znajdowały się w nich życzenia świąteczne, w formie krótkiego tekstu lub wiersza czy opowiadania oraz artykuły związane z tradycją wigilijną w Polsce oraz innych częściach świata. Sporo miejsca poświęcono na opowiadania dotyczące wspomnień ostatniej wigilii, jej symbolicznego wymiaru. Władysław Miączyński zadedykował swój wiersz Ostatnia Wigilia zmarłej artystce Helenie DuninWeinzieherowej. Ponadto, zamieszczano opowiadania obrazujące celebrowanie i spędzanie świąt przez różne grupy społeczne (dzieci, dorosłych, zdrowych, chorych, bogatych, ubogich), a także różnej maści anegdoty, ciekawostki i dowcipy.

Na uwagę zasługują licznie dołączane wiersze o tematyce bożonarodzeniowej. Znalazły się tam lityki m.in. W noc wigilijna Józefa Karpińskiego, Moja choinka Kazimierza Laskowskiego, a także Gwiazdka Betlejemska Joanny Podhorskiej-Okołów (podpisany jej pseudonimem „Bożymir”). W jednej z jednodniówek, co ciekawe wydanej w Wilnie, zamieszczono starodawną modlitwę podhalańskich pasterzy do świętego Mikołaja i krótko scharakteryzowano próbując datować jej powstanie na XVI/XVII wiek, twierdząc przy tym, że spisano ją w Maniowach koło Czorsztyna:

33 J. Z. [Jerzy Zapaśnik], Radjo w każdym domu, „Kresowy przegląd radjowy...”, dz. cyt., s. 1 . 


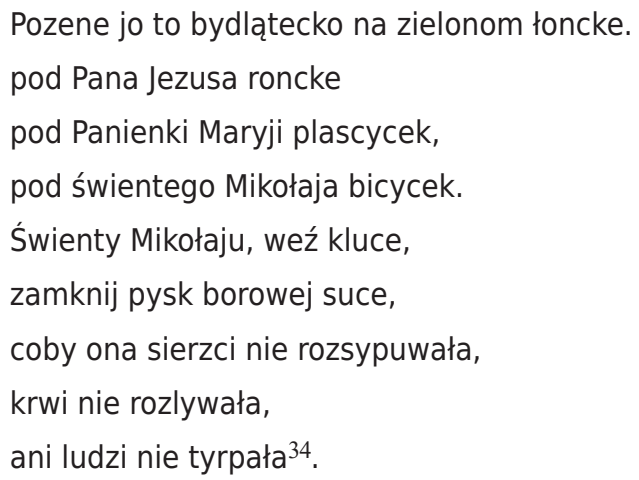

\section{Sposób przekazu}

Ważnym zagadnieniem jest również forma publikacji. Można zauważyć, że starano się przygotować odpowiednio strony tytułowe, na których zazwyczaj znajdowały się niezbędne informacje, takie jak tytuł, miejsce i rok wydania, nazwiska redaktorów i nazwę drukarni, ewentualnie litografii. W wielu drukach pojawiały się również obrazy i rysunki ilustrujące tematykę jednodniówki lub też widoki rozpoznawalne dla mieszkańców danych miast lub ziemi. Okładka takiej publikacji, jak w przypadku innych druków, miała realizować trzy podstawowe funkcje: komunikatywną, ekspresywną i impresywną ${ }^{35}$. Były to niewielkie teksty liczące od jednej do kilkudziesięciu stron, przy czym wyraźnie przeważały druki szesnasto- i dwudziestostronicowe.

Zamieszczane w jednodniówkach materiały miały bardzo różnorodną tematykę i charakter. Znalazły się w nich artykuły, felietony, opowiadania, wiersze, streszczenia, fragmenty korespondencji czy też przemówień, a także depesze. Jako przykład można podać depeszę przysłaną do organizatorów „Dni Mickiewiczowskich" w Nowogródku, w której dziennikarze z całej Polski dziękowali za ciepłe przyjęcie i organizację tego przedsięwzięcia oraz zorganizowaną wycieczkę po Ziemi Nowogródzkiej. Wcześniej, w jednodniówce, podana była lista uczestników wycieczki dla dziennikarzy z podaną afiliacją. Jest to dość interesujące źródło, które może służyć w badaniach czasopiśmienniczych II Rzeczypospolitej. W jednodniówkach, obok artykułów, ważną rolę

34 „Gwiazdka: jednodniówka świąteczna artystyczno-literacka”, Wilno 1936, s. 13.

35 W. Pisarek, Nowa retoryka dziennikarska, Kraków 2002, s. 110 oraz W kulturze pierwszych stron, pod red. I. Borkowskiego, A. Woźnego, Wrocław 2005. 
odgrywały wszelkie ilustracje, zdjęcia czy rysunki. Najczęściej przy tekstach umieszczano konterfekty oraz ilustracje zabytków i pejzaży kojarzących się z konkretną ziemią lub tematyką.

Na ogół inicjatorzy wydawania jednodniówek upatrywali swoich odbiorców w określonych grupach narodowych, społecznych, zawodowych czy politycznych. Niekiedy funkcjonowały one tylko w obiegu pozaksięgarskim, o czym mógł świadczyć mały nakład lub też brak podanej ceny. W przypadku omawianych jednodniówek kierowane były one do uczestników życia kulturalnego, z myślą, że trafią one do jak najszerszego kręgu odbiorców, o czym świadczy m.in. motywacja „Ciotki Albinowej” z wileńskiej rozgłośni radiowej: „To ja tera dowiedziawszy sia, co wynidzi taka drukowana «Jednodniówka» to i mówia, pójda do samego odpowiedzialnego Redachtora, niechaj pozwoli sia dla mnie nadrukować te słowy, to ich będo czytali wszystkie nasze wioskowe i kumowe moje, i te nasze drogie Rodaki, pozostające na Litwie i Łotwie, co to do nas takie piękne listy piszo!"36.

*

Na zakończenie sformułujmy kilka wniosków:

1. Omawiane jednodniówki województw wschodnich okresu międzywojennego nie miały charakteru ściśle literackiego, jednak spełniały swoiste funkcje w procesie komunikacji - popularyzowały wydarzenia kulturalne i dorobek literacki poszczególnych grup społecznych i narodowych. Stawały się często forpocztą dla wielu inicjatyw.

2. Prezentowane jednodniówki nie pretendowały do roli wyczerpujących i często wykorzystywanych źródeł o wysokiej randze, jednak potwierdzały i dokumentowały, niekiedy mało znaną, aktywność społeczności lokalnych. Można z nich otrzymać ciekawą dokumentację wcześniejszej działalności znanych później ludzi pióra, nauki i kultury. W omawianych jednodniówkach odnaleziono działalność radiową Wiktora Trościanki (po II wojnie światowej został publicystą radiowym w Rozgłośni Polskiej Radia Wolna Europa), Joanny Piekarskiej (popularnej później poetki, reżyserki teatralnej, artystki plastyk) i Lecha Beynara (pseud. „Paweł Jasienica”, cenionego historyka, pisarza, eseisty, publicysty), s. 16.

Ciotka Albinowa, Ciotka Albinowa mówi..., „Kresowy przegląd radjowy...”, dz. cyt., 
wiersze Joanny Podhorskiej-Okołów podpisane jej pseudonimem „Bożymir” oraz prace redakcyjne znanego poety żydowskiego Icchaka Perłowa.

3. Warto też zaznaczyć, że tego typu druki, w różnych postaciach (np. jako wydawnictwa pamiątkowe, afisze) ${ }^{37}$ były publikowane od dawna (oprócz upamiętnienia i dokumentacji, utrwalały one określone wydarzenia, ale też tworzyły i kształtowały swego rodzaju wyobrażenia, kreując często pewne „klisze pamięci”). Najczęściej dzieje się tak w procesie oswajania i symbolicznego „porządkowania” wspólnej przestrzeni ${ }^{38}$.

4. Charakter omawianych jednodniówek zależał od odbiorców. Głównym ich celem było zwrócenie uwagi na dorobek i rolę poszczególnych instytucji, grup społecznych, przypomnienie społeczeństwu o roli określonych wydarzeń i miejsc oraz pobudzenie zainteresowania zjawiskami kulturowymi.

5. Inicjatorami powstania jednodniówek pozostawały niemal wszystkie narodowości mieszkające na badanym obszarze. Różne formy aktywności kulturalnej przejawiały żydowskie, litewskie czy białoruskie środowiska, których działalność biegła oddzielnymi torami. Omawiane druki były kierowane przede wszystkim do przedstawicieli danej grupy narodowej. Nawet zamieszczane w nich reklamy wydawały się w głównej mierze uzależnione od narodowych inklinacji.

6. Zdecydowanie dla województwa wileńskiego, nowogródzkiego i po części poleskiego dominującym ośrodkiem wydawniczym pozostawało Wilno. W przypadku województwa wołyńskiego zauważalny był wyraźny wpływ sąsiedztwa Lwowa. Widać to głównie po reprezentacji poszczególnych narodowości, które publikowały przede wszystkim w tych ośrodkach oraz podwójnych adresach wydawniczych, które wskazywały, że gdzie indziej zredagowano publikację, a gdzie indziej ją wydano lub wydrukowano.

\section{$*$}

Jednodniówki są więc interesującym materiałem źródłowym ze względu na dokumentację wydarzeń ważnych dla danej społeczności, najczęściej politycznych, kulturalnych, zawodowych, szkolnych, literackich, towarzy-

37 Zob. m.in. ich dokumentację bibliograficzną F. Sawicka, J. Rupińska, Bibliografia polskich wydawnictw pamiatkowych 1801-1914, Wrocław 1973.

38 S. Uliasz, Literatura pogranicza kultur-aksjologia i poetyka, [w:] Wilno literackie na styku kultur, pod red. T. Bujnickiego i K. Zajasa, Kraków 2007, s. 15. 
skich etc. Wobec braku czy też szczątkowych badań zawartości czasopism z omawianego obszaru w okresie międzywojennym warto sięgnąć po te źródła, które odsłaniają fragmenty życia literackiego czy kulturalnego społeczności zamieszkujących województwa wschodnie II Rzeczypospolitej, tym bardziej, że wydawały je różne środowiska etniczne i społeczne.

\section{Bibliografia}

Balašaitenè D., Litewska poezja międzywojennego Wilna, [w:] Poezja i poeci w Wilnie lat 1920-1940. Studia, pod red. Tadeusza Bujnickiego i Krzysztofa Biedrzyckiego, Kraków 2003, s. 295-310.

Cichoracki P., Województwo poleskie 1921-1939. Z dziejów politycznych, Łomianki 2014.

Encyklopedia wiedzy o książce, red. Aleksander Birkenmajer, Bronisław Kocowski, Jan Trzynadlowski, Wrocław 1971.

Encyklopedia wiedzy o prasie, pod red. Juliana Maślanki, Wrocław 1976.

Fox D., Czasopiśmiennictwo teatralne w latach 1918-1939, Katowice 2013.

Fuks M., Materiały do bibliografii żydowskiej prasy prowincjonalnej wydawanej w Polsce (1918-1939), „Biuletyn Żydowskiego Instytutu Historycznego” 1981, nr 2 (118), s. 65-88.

Głowicka Z., Dokumenty życia społecznego w zbiorach Biblioteki Narodowej, „Biuletyn Informacyjny Biblioteki Narodowej" 2001, nr 1 (156), s. 3-6.

Goban-Klas T., Media i komunikowanie masowe. Teorie i analizy prasy, radia, telewizji i Internetu, Warszawa 1999.

Jarowiecki J., Barbara Góra, Prasa Iwowska w dwudziestoleciu międzywojennym. Próba bibliografii, Kraków 1994.

Kaganowicz S., Teatr żydowski w Wilnie, [w:] Wilno i Kresy północno-wschodnie. Materiały II Międzynarodowej Konferencji w Białymstoku 14-17 IX 1994 r. w czterech tomach. T. II: Kultura i trwanie, pod red. Elżbiety Feliksiak i Alicji Kisielewskiej, Białystok 1996, s. 255-268.

Kallenbach J., O nieznanych utworach młodzieńczych Adama Mickiewicza, „Pamiętnik literacki" 1908, s. 493-494.

Korczyńska-Derkacz M., Jednodniówki jako typ dokumentów życia społecznego. Za- 
rys problematyki badawczej, „Acta Universitatis Wratislaviensis. Bibliotekoznawstwo" 2008 (27), s. 135-148.

Korczyńska-Derkacz M., Polskie jednodniówki okresu międzywojennego jako źródło informacji o życiu młodzieży akademickiej Lwowa (ze zbiorów Biblioteki Narodowej), [w:] Kraków-Lwów: książki, czasopisma, biblioteki XIX i XX wieku, t. 9, cz. 2, pod red. Haliny Kosętki, Barbary Góry, Ewy Wójcik, Kraków 2009, s. 205-218.

Makowski B., Prasa litewskiej mniejszości narodowej w Polsce w latach 1920-1939, „Kwartalnik Historii Prasy Polskiej” 1978, nr 17/1, s. 89-107.

[Obst J.] J. O., Freski w kościele Mścisławskim, „Litwa i Ruś" 1912, t. 2, z. I, s. 28-33.

Pisarek W., Analiza zawartości prasy, Kraków 1983.

Sadowska J., Zimnoch K., Jednodniówki na terenie województwa białostockiego i województw wschodnich (nowogródzkiego, poleskiego, wileńskiego, wołyńskiego) Drugiej Rzeczypospolitej, Białystok 2017.

Uliasz S., Literatura pogranicza kultur - aksjologia i poetyka, [w:] Wilno literackie na styku kultur, pod red. Tadeusza Bujnickiego i Krzysztofa Zajasa, Kraków 2007, s. $11-20$.

W kulturze pierwszych stron, pod red. Igora Borkowskiego, Aleksandra Woźnego, Wrocław 2005.

Zienkiewicz T., Z problematyki polsko-białoruskich związków literackich w międzywojennym Wilnie (Białorusini $i$ ich współpraca z „Przeglądem Wileńskim"), [w:] Wilno literackie na styku kultur, pod red. Tadeusza Bujnickiego i Krzysztofa Zajasa, Kraków 2007, s. 210-220.

Żydowska mozaika polityczna w Polsce 1917-1927: wybór dokumentów, wybór i oprac. Czesława Brzozy, Kraków 2003. 